\title{
PENGARUH METODE PENEMUAN TERBIMBING MENGGUNAKAN LEMBAR KERJA SISWA (LKS) BERBANTUAN GEOGEBRA TERHADAP HASIL BELAJAR MATEMATIKA SISWA KELAS VIII PADA MATERI SISTEM KOORDINAT DI MTS DARU MAFATIHIL ULUM PROBOLINGGO
}

\author{
Ubaydillah Arifin $^{1}$, Umi Farihah ${ }^{2}$ \\ ${ }^{1,2}$ Institut Agama Islam Negeri Jember \\ ubaydillah18.arifin@gmail.com ${ }^{1}$, u_farihah@yahoo.com ${ }^{2}$
}

\begin{abstract}
ABSTRAK
Penelitian ini bertujuan untuk mengetahui pengaruh metode penemuan terbimbing menggunakan lembar kerja siswa (LKS) berbantuan geogebra terhadap hasil belajar matematika siswa kelas VIII pada materi sistem koordinat di MTs Daru Mafatihil Ulum Probolinggo. Metode penemuan terbimbing adalah suatu metode pembelajaran yang menghendaki siswa menemukan ide-ide dalam proses penemuan. Metode penelitian yang digunakan adalah pre-experimental design dengan rancangan penelitian one group pretest posttest design. Pengambilan sampel dilakukan dengan cara cluster random sampling. Teknik pengumpulan data berupa tes, pretest untuk mengetahui hasil belajar matematika siswa sebelum diberikan perlakuan dan posttest untuk mengetahui hasil belajar matematika siswa sesudah diberikan perlakuan. Analisis data menggunakan paired sample t-test dengan uji prasyarat, uji normalitas dan uji homogenitas. Hasil penelitian menunjukkan bahwa terdapat perbedaan hasil belajar matematika siswa kelas VIII pada materi sistem koordinat antara sebelum dan sesudah dibelajarkan dengan metode penemuan terbimbing menggunakan lembar kerja siswa (LKS) berbantuan geogebra di MTs Daru Mafatihil Ulum Probolinggo. Sehingga metode penemuan terbimbing menggunakan LKS berbantuan geogebra dapat digunakan sebagai alternatif pembelajaran yang dapat meningkatkan hasil belajar matematika siswa.
\end{abstract}

Kata kunci: geogebra, hasil belajar, Lembar Kerja Siswa (LKS), metode penemuan terbimbing.

\begin{abstract}
This study aims to determine the effect of the guided discovery method using Geogebraassisted student worksheets on the mathematics learning outcomes of Grade VIII students on the coordinate system material at MTs Daru Mafatihil Ulum Probolinggo. The guided discovery method is a learning method that requires students to find ideas in the discovery process. The research method used was pre-experimental design with one group pretest posttest design research design. Sampling was done by cluster random sampling. Data collection techniques in the form of tests, pretest to know student mathematics learning outcomes before being given treatment and posttest to find out student mathematics learning outcomes after being given treatment. Data analysis used paired sample t-test with prerequisite tests, normality tests and homogeneity tests. The results showed that there were differences in mathematics learning outcomes of VIII grade students in the coordinate system material between before and after they were taught with the guided discovery method using Geogebra-assisted student worksheets in MTs Daru Mafatihil Ulum Probolinggo. So the guided discovery method using geogebra-assisted worksheet can be used as an alternative learning that can improve student mathematics learning outcomes.
\end{abstract}

Keywords: geogebra, learning outcomes, student worksheet (LKS), guided discovery method. 


\section{PENDAHULUAN}

Kemajuan suatu bangsa ditentukan dari bagaimana perkembangan pendidikan bagi anak bangsa itu. Kemajuan dalam satuan waktu jangka panjang dapat memprediksi kualitas bangsa pada sekian puluh tahun kedepan (Hamzah, 2014). Matematika merupakan ilmu yang mendasari perkembangan teknologi modern yang mempunyai peran penting dalam berbagai disiplin ilmu dan dapat mengembangkan daya pikir manusia (Maxrizal, 2010). Selain itu, matematika juga tidak dapat dipisahkan dari ilmu pengetahuan dan teknologi. Perkembangan teknologi informasi dan komunikasi (TIK) atau teknologi berbasis komputer telah memberikan pengaruh terhadap dunia pendidikan khususnya dalam proses pembelajaran (Tamami, 2014).

Mata pelajaran matematika diajarkan pada setiap jenjang pendidikan mulai dari prasekolah (TK), SD, SMP, SMA, sampai pada tingkat perguruan tinggi (Manik \& Mukhtar, 2017). Oleh karena itu matematika menjadi salah satu pelajaran yang sangat penting bagi manusia. Salah satu materi yang dipelajari siswa di tingkat SMP/MTs kelas VIII adalah materi Sistem Koordinat. Visualisasi konsep untuk menentukan tiap titik dalam bidang, dengan memanfaatkan media pembelajaran berbantuan software Geogebra, diharapkan dapat menambah minat dan motivasi siswa untuk belajar sehingga konstruksi konsep terbentuk dengan baik dan membuat proses belajar mengajar menjadi lebih menyenangkan. Geogebra merupakan salah satu software bantu yang cukup lengkap dan digunakan secara luas. Nama Geogebra merupakan kependekan dari Geometry (geometri) dan Algebra (aljabar). Meski dari sisi nama hanya merujuk geometri dan aljabar, aplikasi ini tidak hanya untuk kedua topik tersebut, tetapi juga mendukung banyak topik matematika di luar keduanya.

Menurut Majid dalam Sari (2014) Siswa dapat memahami materi dengan baik apabila siswa belajar materi tersebut secara mandiri. Salah satu altermatif bahan ajar yang dapat digunakan untuk mengarahkan pola pikir siswa dan membangun kemandirian siswa adalah Lembar Kerja Siswa (LKS). LKS berisi tugas dan langkah-langkah yang menuntun siswa mengelola pola pikir secara terarah. Peran guru sebagai fasilitatorpun dapat dimaksimalkan. DenganLKS 


\section{Pengaruh Metode Penemuan Terbimbing Menggunakan Lembar Kerja Siswa (LKS) Berbantuan Geogebra Terhadap Hasil Belajar Matematika Siswa Kelas VIII pada Materi Sistem Koordinat di MTs Daru Mafatihil Ulum Probolinggo}

diharapkan siswa dapat belajar secara mandiri, memahami dan menjalankan sesuatu secara tertulis.

Metode penemuan terbimbing adalah mengubah kondisi belajar yang pasif menjadi aktif dan kreatif. Mengubah pembelajaran yang teacher oriented dimana guru menjadi pusat informasi menjadi student oriented dimana siswa menjadi subjek aktif belajar yang menuntut siswa secara aktif menemukan informasi sendiri melalui bimbingan (Sari, 2014). Metode ini lebih mengarahkan peserta didik untuk berfikir dan belajar menemukan pengetahuan sendiri sehingga dengan menggunakan metode pembelajaran ini, peserta didik lebih mudah memahami konsep pokok bahasan Sistem Koordinat, sehingga ketika peserta didik dihadapi dengan sebuah pertanyaan ia bisa menjawabnya, dan hasil belajar matematika siswa pun jauh lebih baik (Nufus, 2015).

Menurut Susanto dalam Rahayuningsih (2016) makna dari hasil belajar yaitu perubahan yang terjadi pada diri siswa, baik yang menyangkut aspek kognitif, afektif, dan psikomotor sebagai hasil dari kegiatan belajar. Menurut Nashar dalam Setyowati (2007) hasil belajar juga merupakan kemampuan yang diperoleh siswa setelah melalui kegiatan belajar. Karena belajar merupakan suatu proses dari seseorang yang berusaha untuk memperoleh suatu bentuk perubahan perilaku yang relatif menetap.

Berdasarkan penelitian Khairun Nufus (2015) yang dilakukan di MI I'anatul Huda Tangerang Selatan menunjukkan bahwa nilai rata-rata peserta didik yang menggunakan metode penemuan terbimbing lebih besar di bandingkan dengan nilai rata-rata peserta didik yang menggunakan metode konvensional, yaitu sebesar 82,22 untuk kelas yang menggunakan metode penemuan terbimbing dan 65,14 untuk kelas yang menggunakan metode konvensional.

Penelitian yang dilakukan oleh Umi Farihah (2015) yang dilakukan di MTsN Kampak Trenggalek menunjukkan bahwa motivasi belajar dan hasil belajar siswa yang menggunakan program interaktif Geogebra pada pembelajaran grafik persamaan garis lurus lebih tinggi daripada siswa yang tidak menggunakan program interaktif Geogebra. Berdasarkan permasalahan tersebut, penelitian ini bertujuan untuk mengetahui pengaruh metode penemuan terbimbing 
menggunakan lembar kerja siswa (LKS) berbantuan geogebra terhadap hasil belajar matematika siswa kelas VIII pada materi sistem koordinat di mts daru mafatihil ulum probolinggo.

\section{METODE PENELITIAN}

Jenis penelitian ini merupakan Pre-Experimental Design. Penelitian ini tidak memasukkan kelompok kontrol atau masih ada variabel luar yang ikut berpengaruh terhadap variabel dependen (Jakni, 2016). Bentuk dalam penelitian ini menggunakan One-Group Pretest-Posttest Design. Populasi penelitian ini adalah seluruh siswa kelas VIII di MTs Daru Mafatihil Ulum Probolinggo. Dalam penelitian ini, peneliti menggunakan teknik cluster random sampling, Dari dua kelas yang ada di MTs Daru Mafatihil Ulum diambil satu kelas secara acak yaitu kelas VIII A sebagai kelas eksperimen yang terdiri dari 28 siswa.

Teknik pengumpulkan data pada penelitian ini adalah tes. Tes merupakan sekumpulan pertanyaan yang digunakan untuk mengumpulkan data mengenai kemampuan kognitif siswa sebelum dan sesudah proses pembelajaran berlangsung (Jakni, 2016). Data penelitian ini diambil dari pretest dan posttest hasil belajar siswa pada kelas VIII A dengan materi Pola Bilangan (Pre-Test) dan Sistem Koordinat (Post-Test). Tes yang diberikan kepada kelas VIII Amerupakan tes uraian, dengan jumlah soal lima butir yang mengacu pada indikator penemuan terbimbing. Dalam penelitian ini, dilakukan pengujian validitas yang terdiri dari validitas isi atau kontrak. Instrumen yang diuji kevalidannya yaitu soal pretest dan posttest. Reliabilitas soal merupakan ukuran yang menyatakan tingkat kekonsistenan suatu soal tes (Jakni, 2016). Dalam penelitian ini pengujian reliabilitas menggunakan Cronbach's Alpha. Nilai Cronbach's Alpha menjadi acuan menurut Ruseffendi dalam Jakni (2016). Setelah hasil instrumen memenuhi persyaratan valid selanjutnya dilakukan uji paired sample t-test, sebelumnya data juga harus dilakukan uji normalitas dan homogenitas. 


\section{Pengaruh Metode Penemuan Terbimbing Menggunakan Lembar Kerja Siswa (LKS) Berbantuan Geogebra Terhadap Hasil Belajar Matematika Siswa Kelas VIII pada Materi Sistem Koordinat di MTs Daru Mafatihil Ulum Probolinggo}

\section{HASIL PENELITIAN DAN PEMBAHASAN}

Data hasil penelitian ini berupa pretest dan posttest hasil belajar matematika siswa. Data dianalisis untuk mengetahui perbedaan hasil belajar matematika siswa kelas VIII A.

1. Hasil Pretest

Sebelum pembelajaran materi sistem koordinat, siswa diberikan pretest dengan tujuan untuk mengetahui hasil belajar matematika siswa sebelum diberikan perlakuan. Hasil pretest yang diperoleh siswa kelas eksperimen sebagai berikut:

Tabel 1. Data Pretest

\begin{tabular}{ccccc}
\hline Kelas & Min & Max & Rata-rata & Standar Deviasi \\
\hline Eksperimen & 47 & 80 & 61,90 & 7,559
\end{tabular}

Berdasarkan Tabel 1 dapat diketahui bahwa nilai rata-rata pretest kelas eksperimen adalah 61,90 dengan standar deviasi 7,559.

2. Hasil Posttest

Setelah pembelajaran sistem koordinat selesai, siswa diberikan posttest. Hasil posttest bertujuan untuk mengetahui hasil belajar matematika siswa setelah diberikan perlakuan.

Tabel 2. Data Posttest

\begin{tabular}{ccccc}
\hline Kelas & Min & Max & Rata-rata & Standar Deviasi \\
\hline Eksperimen & 70 & 90 & 80,12 & 5,480
\end{tabular}

Berdasarkan Tabel 2 dapat diketahui bahwa nilai rata-rata posttest 80,12 dengan standar deviasi 5,480. Berdasarkan data diatas diketahui bahwa hasil pretest lebih kecil daripada hasil posttest. Rata-rata hasil belajar matematika siswa (pretest) adalah 61,90 dan rata-rata hasil belajar matematika siswa (posttest) adalah 80,12.

3. Pengaruh Metode Penemuan Terbimbing Menggunakan Lembar Kerja Siswa (LKS) Berbantuan Geogebra terhadap Hasil Belajar Matematika Siswa

Data dalam penelitian ini berdistribusi normal dan homogen maka prasyarat terpenuhi untuk melakukan uji paired sample t-test. Penelitian ini 


\section{Ubaydillah Arifin, Umi Farihah}

bertujuan untuk mengetahui apakah terdapat perbedaan rata-rata dua kelompok data yang diperoleh dari satu kelompok subjek yaitu pretest dan posttest. Berdasarkan kriteria pengujian paired sample t-test hasil analisis penelitian ini adalah $t_{\text {hitung }}>t_{\text {tabel }}$ yaitu 8,869 $>2,048$ dengan signifikan $0,000<0,05$ maka $\mathrm{H}_{\mathrm{a}}$ diterima dan $\mathrm{H}_{0}$ ditolak. Hasil uji hipotesis tersebut dapat disimpulkan bahwa terdapat perbedaan hasil belajar matematika siswa yang signifikan, antara sebelum dan sesudah dibelajarkan dengan metode penemuan terbimbing menggunakan Lembar Kerja Siswa (LKS) berbantuan geogebra pada materi sistem koordinat.

Secara keseluruhan penelitian ini mendukung penelitian sebelumnya yang dilakukan oleh Persada (2016) yang dilakukan di SMPN 2 Sindangagung Kabupaten Kuningan, yang menemukan bahwa adanya pengaruh metode pembelajaran penemuan terbimbing terhadap kemampuan koneksi matematika siswa. Penelitian tersebut diperkuat oleh penelitian Farihah (2015) yang dilakukan di MTs Negeri Kampak Trenggalek, yang menemukan bahwa hasil belajar siswa yang menggunakan program interaktif geogebra pada pembelajaran grafik persamaan garis lurus lebih baik daripada siswa yang tidak menggunakan program interaktif geogebra.

Salah satu metode pembelajaran yang dapat meningkatkan hasil belajar siswa yaitu metode pembelajaran penemuan terbimbing. Manfaat dari metode pembelajaran penemuan terbimbing ini siswa aktif dalam kegiatan pembelajaran, memberikan wahana interaksi antar siswa maupun siswa dengan guru. Lembar Kerja Siswa (LKS) merupakan perpaduan teks dan gambar yang dapat menambah daya tarik kepada siswa sehingga memperlancar penyampaian informasi yang disajikan dalam format verbal dan visual. Sedangkan manfaat dari software geogebra dalam pembelajaran matematika yaitu sebagai media demonstrasi dan visualisasi, sebagai alat bantu konstruksi, sebagai alat bantu penemuan, dan sebagai alat bantu mempersiapkan materi mengajar. Hal ini ditunjukkan dengan adanya perbedaan rata-rata pretest dan rata-rata posttest hasil belajar matematika siswa sebelum dan sesudah dibelajarkan dengan metode penemuan terbimbing menggunakan Lembar Kerja Siswa (LKS) berbantuan geogebra. 


\section{Pengaruh Metode Penemuan Terbimbing Menggunakan Lembar Kerja Siswa (LKS) Berbantuan Geogebra Terhadap Hasil Belajar Matematika Siswa Kelas VIII pada Materi Sistem Koordinat di MTs Daru Mafatihil Ulum Probolinggo}

\section{SIMPULAN}

Terdapat perbedaan hasil belajar matematika siswa kelas VIII A pada materi sistem koordinat sebelum dan sesudah dibelajarkan dengan metode penemuan terbimbing menggunakan lembar kerja siswa (LKS) berbantuan geogebra di MTs Daru Mafatihil Ulum Probolinggo. Hal ini ditunjukkan dari hasil uji paired sample t-test pada taraf signifikan 0,05 diperoleh $t_{\text {hitung }}$ sebesar 8,869 dan $t_{\text {tabel }}$ sebesar 2,048, hal ini menunjukkan $t_{\text {hitung }}>t_{\text {tabel }}$. Dari hasil pengujian yang diperoleh maka ada pengaruh metode penemuan terbimbing menggunakan lembar kerja siswa (LKS) berbantuan Geogebra terhadap hasil belajar matematika siswa kelas VIII pada materi sistem koordinat di MTs Daru Mafatihil Ulum Probolinggo.

\section{DAFTAR PUSTAKA}

Farihah, U. (2015). Pengaruh Program Interaktif Geogebra Terhadap Motivasi dan Hasil Belajar Siswa pada Materi Grafik Persamaan Garis Lurus. Jurnal Pendidikan dan Pembelajaran Matematika (JP2M), 1(1), 11-23.

Hamzah, A. (2014). Evaluasi Pembelajaran Matematika. Jakarta: Rajagrafindo Persada.

Jakni. (2016). Metodologi Penelitian Eksperimen Bidang Pendidikan. Bandung: Alfabeta.

Manik, Mariani \& Mukhtar. (2017). Penerapan Metode Penemuan Terbimbing dalam Upaya Meningkatkan Kemampuan Pemahaman Konsep Matematika di Kelas VIII SMP Negeri 1 Ajibata. Inspiratif: Jurnal Pendidikan Matematika, 3(2), 92-101.

Maxrizal. (2010). Penggunaan Software Geogebra dengan Metode Penemuan Terbimbing untuk Meningkatkan Motivasi Belajar pada Materi Segiempat bagi Siswa Kelas VIIC SMPN 2 Depok. Skripsi. Diterbitkan. Universitas Negeri Yogyakarta.

Nufus, K. (2015). Pengaruh Metode Penemuan Terbimbing Terhadap Hasil Belajar Matematika. Skripsi. Diterbitkan. Universitas Negeri Syarif Hidayatullah Jakarta.

Persada, A. R. (2016). Pengaruh Model Pembelajaran Penemuan (Discovery Learning) Terhadap Kemampuan Koneksi Matematika Siswa (Studi Eksperimen Terhadap Siswa Kelas VII SMPN 2 Sindangagung Kabupaten Kuningan pada Pokok Bahasan Segiempat). EduMa, 5(2), 23-33.

Rahayuningsih, R. (2016). Pengembangan Modul Pembelajaran Berbantuan Software Geogebra untuk Mendukung Hasil Belajar dan Motivasi Belajar Siswa pada Materi Segitiga di Kelas VII SMPK Kemasyarakatan Kalibawang Tahun Ajaran 2015/2016. Skripsi. Diterbitkan. Universitas Sanata Dharma Yogyakarta. 
Sari, R. P. (2014). Pengembangan Lembar Kerja Siswa Berbasis Penemuan Terbimbing pada Materi Lingkaran Kelas VIII di SMP Negeri 4 Kota Bengkulu. Skripsi. Diterbitkan. Universitas Bengkulu.

Setyowati. (2007). Pengaruh Motivasi Belajar Terhadap Hasil Belajar Siswa Kelas VII SMPN 13 Semarang. Skripsi. Diterbitkan. Universitas Negeri Semarang.

Tamami, R. (2014). Pemanfaatan Media Pembelajaran Interaktif (MPI) Powerpoint untuk Visualisasi Konsep Menggambar Grafik Persamaan Garis Lurus. Indonesian Digital Journal of Mathematics and Education, $1(1), 1-12$. 